\title{
The Impact of Parents' Involvement in and Attitude toward Their Children's Foreign Language Programs for Learning English
}

\author{
Vida Hosseinpour \\ Islamic Azad University, Science and Research Branch, Saveh/Faculty of Foreign Languages, Saveh, Iran \\ E-mail: V.hoseinpour@yahoo.com \\ Maryam Sherkatolabbasi (Corresponding author) \\ E-mail: mary.sherkat@yahoo.com \\ Mojgann Yarahmadi \\ Islamic Azad University, Arak Branch, Arak, Iran \\ E-mail: mojgan.yarahmadi@yahoo.com
}

Received: 12-12- 2014

Published: 01-07- 2015
Accepted: 14-02- 2015

doi:10.7575/aiac.ijalel.v.4n.4p.175
Advance Access Published: February 2015

URL: http://dx.doi.org/10.7575/aiac.ijalel.v.4n.4p.175

\begin{abstract}
Since parents and their involvement and attitude have a crucial role in children's achievement in learning English, the present study is to explore and evaluate the impact of Iranian parents' involvement in and attitude toward their children's foreign language programs for learning English. In other words, the effectiveness of their high level of involvement and strength of attitude will be evaluated. Besides, this study is to explore whether some factors such as parents' gender, knowledge of English, income, and educational background are related in the parents' involvement and attitude or not. To this end, first of all, a reliable questionnaire, checked through a pilot study, was distributed among 140 parents to find out the level of their involvement in and attitude toward the programs. Based on the normal curve and the $\mathrm{Z}$ score, the parents were divided into two groups, one with a higher level of involvement and more positive attitude and the other with a lower level of involvement and less positive attitude. By using a standard final achievement test of the course book among 70 primary school student in third grade and Independent T-test analysis, the impact of parents' involvement and attitude were checked. As the results revealed those parents who have high level of involvement in and positive attitude toward their children's English language programs made their children's higher level of achievement in the language program. Besides, the further outcomes showed that there are significant differences between the parents' knowledge of English, income, and educational background and their level of involvement and attitude. The aforementioned factors affect children's achievement test scores as well.
\end{abstract}

Keywords: Involvement, Attitude, and Language program

\section{Introduction}

English language is considered an international language for a long time. Since English is a "global language" and widely used in science and business, the number of English language learners has raised worldwide (Crystal, 2003). More specifically, English is considered as the most significant foreign language in Iran and it has an important role in education.

The notion of when it comes to English learning, the younger the better, is widely accepted by people (Wang and Chang, 2011; Birdsong and Molis, 2001). It is proven that childhood education has to begin early and children learn most at early ages. Foreign language instruction in primary school has been justified by educators and experts with theoretical and empirical rationale. More particularly to the context of this study, Iranian parents are increasingly interested in English learning for their children from the early ages. Thus, this increasing significance of mastering English seems to have encouraged more primary schools to include English language programs as a subject in their curriculum.

Regarding the parents' roles, the impact of parents on children's development and education is really crucial and it has been the topic of empirical studies for a long time. Parents are always in the center of their children's life. Family or parents is an environmental factor that affects learners' academic achievements.

Traditionally parents think that teachers and schools are the only responsible agents for their children's education and training. As teachers try to make a relationship with parents so that they involve the parents in their children's education, parents may perceive teachers as being not appropriate teachers. The teacher must enlighten the parents on the physical, spiritual, mental, and emotional development of their children. (Latif, Rahmany \& Hassani, 2013) 
As it was mentioned, a child's family is the most influential part of his/her life. Therefore, parents have a major role in their children's education. Parents' involvement in and attitude toward a foreign language has a great effect on their children's success in learning the language. This attitude can be passive or active. It is shown that children have a better foreign language achievement if their parents have an active attitude towards this foreign language even if these parents do not speak the foreign language. And vice versa is true if the parents have a passive attitude towards a foreign language. Parents can reveal their positive attitudes towards foreign language learning by being a part of their child's learning inside or outside of the school (Rosenbusch, 1987).

Parents' attitudes toward language learning are especially important in concepts when predicting children's level of success in language attainment (Baker, 1992). To the extent that parents definitely understand advantages of language learning and how to develop it, their children's foreign language learning will be more effective via language programs.

In case of parents' involvement, Feuerstein (1990) stated that parents have cognitive, social, and emotional roles in students' development. They can form their students' self-concepts and through this efficient cognitive functioning, foster their language learning. This feature is culture-bound and differs in different societies (as cited in Williams and Burden, 1997). Buttery and Anderson (2000) documented that parents play an active role by monitoring their children's activities. Parents might play a more indirect role by modeling attitudes that leads to language learning achievement. Keith and Keith (1993) confirmed that involvement by parents is particularly significant in work with young children. Parents can help their children in experiencing and making sense of the world. Parents also provide an important source of emotional.

Thus, owing to the fact that a growing body of research has confirmed the role of parents' involvement in and attitude toward their children' language learning, it is of utmost importance to see how effective it is in students' achievement and development in practice.

Based on the purpose of the research, the present study seeks to answer the following questions. The first question is the main research question and the last four ones are considered as the minor ones:

1. Do the students whose parents have high level of involvement in and positive attitude toward their children's English language programs learn and achieve more in the programs?

2. Is there any significant difference between parents' knowledge of English and their involvement in and attitude toward their children's English language programs?

3. Is there any significant difference between parents' gender and their involvement in and attitude toward their children's English language programs?

4. Is there any significant difference between parents' level of educational background and their involvement in and attitude toward their children's English language programs?

5. Is there any significant difference between parents' level of income and their involvement in and attitude toward their children's English language programs?

\section{Review of the Related Literature}

The purpose of this section is to review the literature relating to the theoretical and research issues so as to provide input into the construction of the framework for the present study. The theoretical and research background related to the effect of parents' involvement in attitude toward children's language programs for learning English is addressed herein respectively.

\subsection{Theoretical Background}

Foreign language teaching in early ages or specifically elementary school has been justified by educators and experts with theoretical and empirical rationale. Theories and research suggests early onset and sustained study of second and third languages cause more effective conversational proficiency (McGroarty, 1997 \& Brown, 2007), advantageous to those students' future educational and occupational purposes.

According to Ballantyne, Sanderman, \& McLaughlin (2008), early childhood language programs can play an essential role in preparing young English language learners for later achievements in education. Children who have an opportunity to develop basic foundational skills in language and literacy in school programs will be more successful.

In both theory and practice, it is extremely concluded that in early childhood development, parents especially mothers play a crucial role in young children's life therefore parental education is important for the healthy development of children (Oncu \& Unluer, 2010).

Parents', teachers' and students' beliefs are significantly important, since they can help conversations concerning the status of foreign languages and have effects on every language policy decision and determine a new direction for education, (Griva \& Chostelidou, 2011; Nespor, 1987). Parents can play an important role in terms of improving children's positive thinking towards foreign languages. Parental attitudes towards foreign languages influence their children's success in multilingual competence. Both the way in which parents feel about foreign languages and the way they treat have effects on their children linguistic development (Young, 1994). Besides, Parents' attitudes, motivations and home literacy practices can be affected by a variety of personal characteristics such as age, gender, educational levels, income etc. (Jang, 2012).

Generally, concept of parents' attitudes is important in understanding children's language attainment because they influence parents' language behavior with regards to children's language learning (Tse, 1998, cited in Jang, 2012). In other words, parents' attitudes toward languages considerably affect children's attitudes (Baker, 1992). 
In case of involvement, Keith and Keith (1993) confirmed that involvement by parents is particularly significant in work with young children. Parents can help their children in experiencing and making sense of the world. Parents also provide an important source of emotional.

The literature related to parents and language programs at schools is rife with articles that convey a convincing and positive connection between parent involvement and academic achievement (Henderson \& Mapp, 2002), school attendance (Sheldon, 2002), graduation rates (Harvard Family Research Project, 2006), educational aspirations (Greenwood \& Hickman, 1991), positive classroom behavior (Cotton \& Wikeland, 2001), enrollment in more challenging curricula, and favorable attitudes towards language program (Henderson \& Mapp, 2002; Trusty, 1996; Astone \& McClanahan, 1991).

\subsection{Research background}

Boosting in the numbers of language institutes and their students, also boosting interest of parents for their children to learn English can be a good evidence for the recent importance of English language programs in Iran (Vaezi, 2008).

However, it should be mentioned that teaching of English has long been a difficult task for both EFL students and teachers in Iran due to reasons such as lack of resources and little contact with the target language (Sadeghi, 2005).

Oladejo (2006) examined parents' attitudes towards bilingual education policy in Taiwan. The results of this study indicated that gender was not related to parents' attitudes toward bilingual education. However, there was a significant difference between age and parents' opinions on the statements claiming that foreign language learning would negatively influence children's first language proficiency. The parents' income was also influential. Lower income parents were less likely to agree than higher income parents. In the same question, the highly educated parents had more positive response than the lower educated parents.

Furthermore, in another study, the components of parents' language attitudes and involvement were also influenced by a variety of factors such a gender, ethnic background, parents' language background, social class and income level (Cansler, 2008).

In addition, a great deal of studies (Craig, 1996; Giacchino-Baker, \& Piller, 2006) in relation to parents' attitudes and motivations were conducted in second language learning contexts, whereas much less research was implemented in foreign language contexts (Chalak, \& Kassaian, 2010; Csizer \& Dörnyei, 2002).

Many studies confirm significant effects of parents' involvement for example, August and Hakuta (1997) stated that parent involvement could provide a significant source of support for students and teachers. Previous researches (e.g. Carter \& Nunan, 2001; Waterman \& Harry, 2008; Clark, \& Hawkins, 2010) have suggested that parent involvement is central to academic achievement.

To put it in a nutshell, the direct correlation between parental attitude and involvement in various capacities of schooling and student achievement has been documented in many empirical investigations (Cansler, 2008).

\subsection{The current state of Children's English language programs in Iran}

English is the most important foreign language in Iran because it is a mandatory subject at secondary schools and high school and generally in higher education. Many Iranians would consider English as their children's second important language to learn. English skills are a requirement for most official jobs and are often crucial to improving one's career. As it was mentioned above, English is a significant subject on entrance exams of high-ranking university admissions.

Thus, most of Iranian parents are increasingly interested in bilingualism for their children and they want primary schools to have English learning program as a school subject. Based on the review of the literature, almost all parents' attitudes, motivations toward and involvement in language learning are especially important in concepts when predicting children's level of success in language achievement.

\section{Methodology}

The design of this study is both descriptive and experimental. Since a questionnaire as one of the most common method of collecting quantitative data in applied linguistics is utilized to get parents' involvement in and attitude toward their children's English language programs, the present study first employed a quantitative method and a descriptive design.

Regarding the experimental design, as the main research design of the study to see the effects of parents' involvement in and attitude toward their children's English language programs, the study employed a two-group posttest-only randomized experimental design.

A pilot study was employed to examine the feasibility of the researcher-adapted questionnaire from the study which was carried out by Lois Elaine McLendon Cansler in North Carolina in 2008 and check the length, layout and item sequence since no previous research had been found in the context of Iran as a survey study in this regard. After administration of the questionnaires in the pilot study which was to check reliability and validity, PASW Statistics (SPSS version 18) software was used in order to calculate Cronbach's alpha internal consistency reliability of the questionnaire. According to the reliability statistics, the questionnaire yielded a Cronbach's alpha of 0.87 revealing satisfactory internal consistency reliability indexes which were highly acceptable. 


\subsection{Participants of the questionnaire}

Participants of this study consisted of both students' fathers and mothers from Ferdows primary school in Tehran, Iran. As it mentioned before, all the students participating in the research were girls. It should be mentioned that both parents of a student were asked to participate and they were recognizable by the codes that the researcher assigned. They were randomly selected parents of school through the third grade students taking part in English Time 2 course.

A total of 140 parents (70 fathers and 70 mothers) were accessed through their children attending the third grade of the primary school selected from a district with similar socio-economical levels. The parents were asked whether their children attend other English programs out of school or not and those whose children take part only in school language programs which was true about almost all of students were chosen to take part in the study. The school was chosen based on information presented on its website indicating that the school had a foreign language program.

Based on the nature of the questions in questionnaire, in order to categorize the parents in two groups, one with high level of involvement and positive attitude and the other with a lower level of involvement and less positive attitude, a normal curve was employed. The data will be presented in the following.

\subsection{Participants of post-test}

The students who participated in the present study were 70 ones who selected according to their parents' total score (in both involvement and attitude) in questionnaire. Thus, there are two groups of students, the ones whose parents have a high level of involvement and positive attitude and the others whose parents have a lower level of involvement and less positive attitude. According to the similar codes which were assigned to the parents and their children, the total score of parents in questionnaire and the students' achievement test score will be compared to see the effect of the parents' involvement in and attitude toward language learning program.

\subsection{Instruments}

As mentioned in research design section, this study utilized a questionnaire to get parents' involvement in and attitude toward their children's English language programs and divide them into two groups of parents with high level of involvement and positive attitude and vice versa. Afterwards, this study employed a standard final achievement test of the book, English time 2, in order to check the students' achievement and then the effect of their parents' involvement in and attitude toward their children's English language programs.

\section{Results}

First, based on the questionnaires analysis and according to the normal curve and $\mathrm{Z}$ score, the researcher found two groups of participants among the parents. The following graph and tables reveal the distribution of the parents:

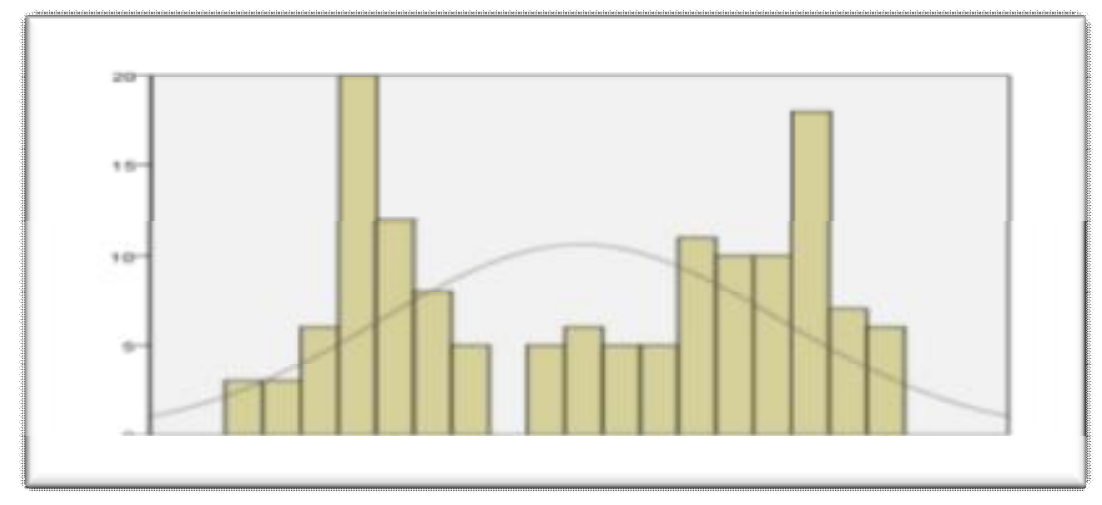

Figure 1. Frequency distribution of participants based on attitude and involvement variables

Table 1. The Z Score for Involvement and Attitude Variables

\begin{tabular}{llll}
\hline & & Statistic & Std. Error \\
\hline both & & 3.7549 & .06813 \\
& Mean & Lower Bound & 3.6202 \\
& S\% Confidence Interval for Mean & 3.8896 \\
& Upper Bound & 3.7613 \\
Median & & 3.9231 \\
Variance & .650 \\
Std. Deviation & .80612 \\
Minimum & 2.38 \\
Maximum & 4.92 \\
Range & 2.54 \\
Interquartile Range & 1.54 \\
Skewness & -.117 \\
Kurtosis & -1.531 \\
\end{tabular}


Based on the $\mathrm{Z}$ score, two classes were defined as Lower Bound and Upper Bound ones. Those parents whose total scores of the questionnaire were lower than the Lower Bound number which was about 3.6 were defined as the parents having a lower level of involvement in and less positive attitude toward their children's language program.

On the other hand, those parents whose total scores of the questionnaire were higher than the Upper Bound number which was about 3.9 were defined as the parents having a higher level of involvement in and more positive attitude toward their children's language program.

\subsection{Descriptive data of defining the main variables}

Table 2. Defining the Main Variables

COMPUTE Attitude $=(a 1+a 2+a 3+a 4+a 5+a 9+a 10+a 13) / 8$. EXECUTE.

COMPUTE Involvement $=(i 6+i 7+i 8+i 11+i 12) / 5$. EXECUTE.

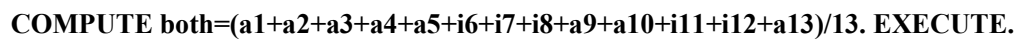

According to the computation on SPSS, adding the following ordinal questions a1 $+\mathrm{a} 2+\mathrm{a} 3+\mathrm{a} 4+\mathrm{a} 5+\mathrm{a} 9$ + a10 + a13 divided by 8 defines the main interval variable of attitude. It is worth mentioning that by adding the ordinal questions here, the interval variable of attitude was gotten.

Besides, adding the following ordinal questions $\mathrm{i} 6+\mathrm{i} 7+\mathrm{i} 8+\mathrm{i} 11+\mathrm{i} 12$ divided by 5 defines the main interval variable of involvement. Again here, by adding the ordinal questions here, the interval variable of involvement was calculated.

Furthermore, in order to have a variable to represent both attitude and involvement variables, all 13 questions of the questionnaire were added and divided by the total number of the ordinal questions and finally the interval variable showing both attitude and involvement turned out.

\subsection{Responding the research Questions}

To answer the research questions, Independent Sample Tests and ANOVA analysis were employed.

1. Do the students whose parents have high level of involvement in and positive attitude toward their children's English language programs learn and achieve more in the programs?

The following tables depict the results related to the first major research question:

Table 3. Group Statistics of Both Level of Involvement and Strength of Attitude and Students' Achievement Test Scores

\begin{tabular}{llllll}
\hline & both & $\mathrm{N}$ & Mean & Std. Deviation & Std. Error Mean \\
\hline class.score & high total score & 35 & 4.3429 & .59125 & .09994 \\
& lower total score & 35 & 2.6000 & .97619 & .16501 \\
\hline
\end{tabular}

Table 4. Independent Samples Test of Strength of Both Level of Involvement and Strength of Attitude and Students' Achievement Test Scores

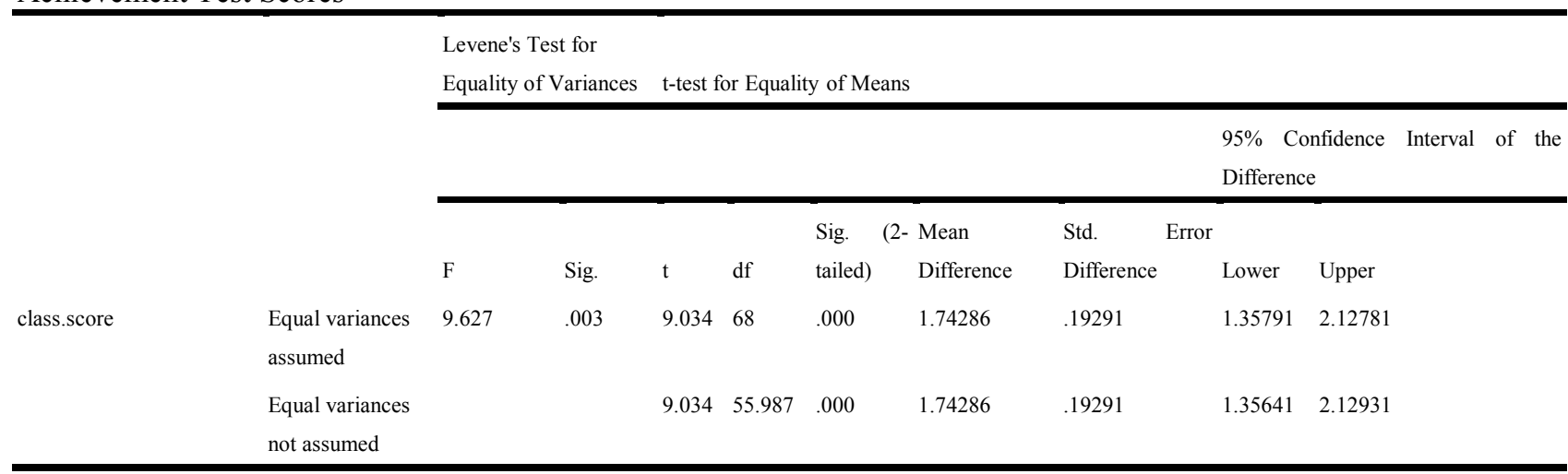

As the above tables and the results of Independent Sample Tests show, there are statistical significant differences, $(p<0.05)$. The outcomes state that there are two independent groups of the students whose parents have different levels of involvement in and attitudes toward their children's English language programs. The scores of the students' achievement test are significantly different considering their parents' level of involvement and attitude. This difference as it was depicted in the first table shows those children whose parents had a higher level of involvement in and a more positive attitude toward their children's English language programs got a higher achievement score. 
2. Is there any significant difference between parents' knowledge of English and their involvement in and attitude toward their children's English language programs?

Table 5. Group Statistics of Parents' Knowledge of English and their Involvement and Attitude

\begin{tabular}{llllll}
\hline & speak.eng & $\mathrm{N}$ & Mean & Std. Deviation & Std. Error Mean \\
\hline both & yes & 38 & 4.2045 & .70779 & .11482 \\
& no & 102 & 3.5875 & .77875 & .07711 \\
\hline
\end{tabular}

Table 6. Independent Samples Test of Parents' Knowledge of English and their Involvement and Attitude

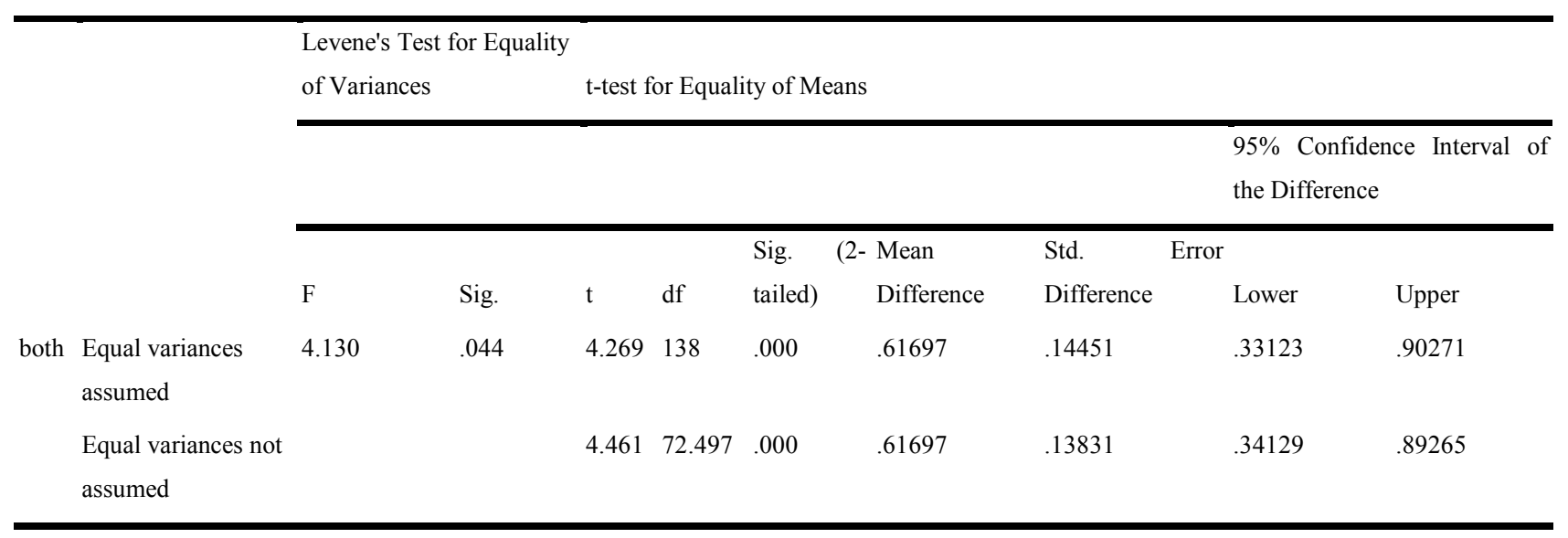

According to above tables, the statistical significant level is below 0.05, $(p<0.05)$, showing that the differences are significant. The parents' knowledge of English shows higher level of involvement and more positive attitudes. Thus, there is a significant difference between parents' knowledge of English and their involvement in and attitude toward their children's English language programs .

3. Is there any significant difference between parents' gender and their involvement in and attitude toward their children's English language programs?

Table 7. Group Statistics of Parents' Gender and their Involvement and Attitude

\begin{tabular}{llllll}
\hline & gender & $\mathrm{N}$ & Mean & Std. Deviation & Std. Error Mean \\
\hline program.value & male & 70 & 3.7429 & 1.11233 & .13295 \\
& female & 70 & 3.7571 & .92369 & .11040 \\
\hline
\end{tabular}

Table 8. Independent Samples Test of Parents' Gender and their Involvement and Attitude

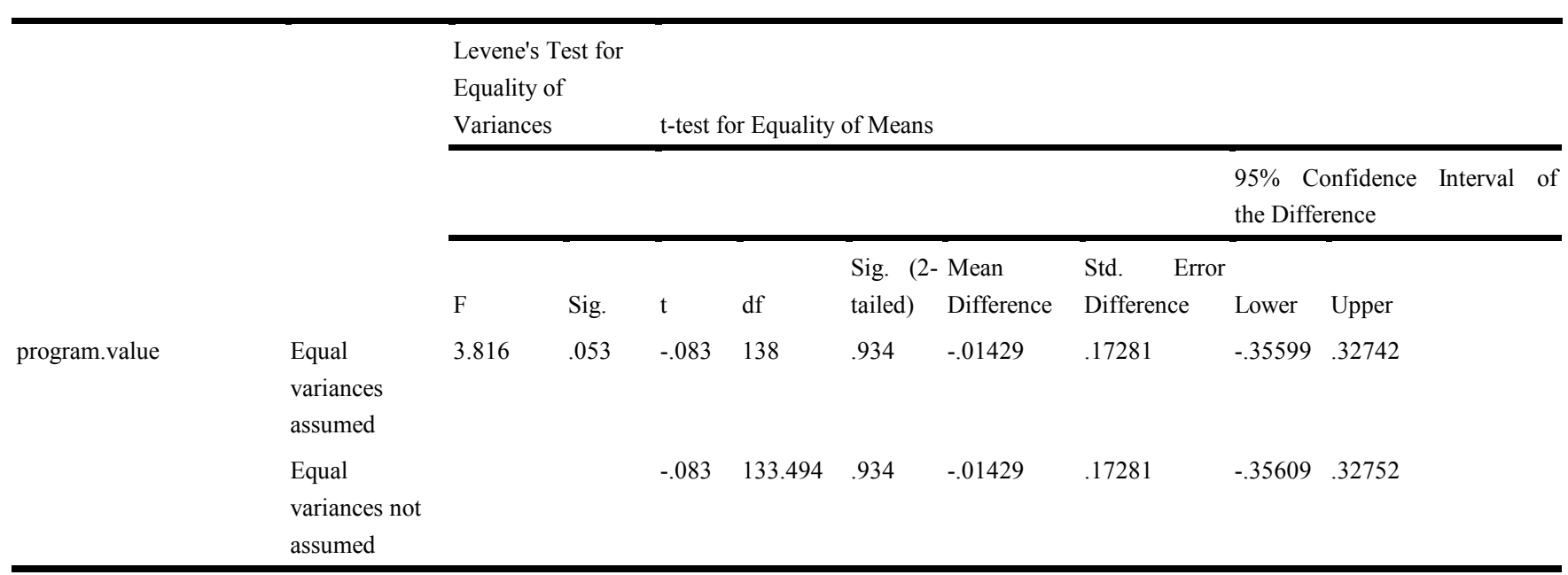

Based on the above tables, the statistical significant level is higher than 0.05 , showing that the differences are not significant. There is not any significant difference between parents' gender and their involvement in and attitude toward their children's English language programs. 
4. Is there any significant difference between parents' level of educational background and their involvement in and attitude toward their children's English language programs?

Table 9. Group Statistics of Parents' Level of Educational Background and their Involvement and Attitude

\begin{tabular}{|c|c|c|c|c|c|c|c|c|}
\hline & \multirow[b]{2}{*}{$\mathrm{N}$} & \multirow[b]{2}{*}{ Mean } & \multirow[b]{2}{*}{ Std. Deviation } & \multirow[b]{2}{*}{ Std. Error } & \multicolumn{2}{|c|}{$95 \%$ Confidence Interval for Mean } & \multirow[b]{2}{*}{ Minimum } & \multirow[b]{2}{*}{ Maximum } \\
\hline & & & & & Lower Bound & Upper Bound & & \\
\hline below diploma & 8 & 2.6827 & .11943 & .04223 & 2.5828 & 2.7825 & 2.54 & 2.77 \\
\hline diploma & 36 & 2.9209 & .26295 & .04382 & 2.8320 & 3.0099 & 2.38 & 3.31 \\
\hline bachelor's degree & 61 & 3.9218 & .66580 & .08525 & 3.7513 & 4.0923 & 2.77 & 4.69 \\
\hline master's degree or higher & 35 & 4.5670 & .25382 & .04290 & 4.4798 & 4.6542 & 4.23 & 4.92 \\
\hline Total & 140 & 3.7549 & .80612 & .06813 & 3.6202 & 3.8896 & 2.38 & 4.92 \\
\hline
\end{tabular}

Table 10. ANOVA Test of Parents' Level of Educational Background and their Involvement and Attitude

\begin{tabular}{llllll}
\hline & Sum of Squares & df & Mean Square & F & Sig. \\
\hline Between Groups & 59.019 & 3 & 19.673 & 85.459 & .000 \\
Within Groups & 31.308 & 136 & .230 & & \\
Total & 90.326 & 139 & & & \\
\hline
\end{tabular}

Based on the tables 9 and 10 and as the results of ANOVA show, the statistical significant level is below 0.05, $(p<0.05)$, showing that the differences are significant. In other words, there is a significant difference between parents' level of educational background-including below diploma, diploma, bachelor's degree, and master's degree or higher- and their involvement in and attitude toward their children's English language programs.

5. Is there any significant difference between parents' level of income and their involvement in and attitude toward their children's English language programs?

Table 11. Group Statistics of Parents' Level of Income and their Involvement and Attitude

\begin{tabular}{|c|c|c|c|c|c|c|c|c|}
\hline & \multirow[b]{3}{*}{$\mathrm{N}$} & \multirow[b]{3}{*}{ Mean } & \multirow[b]{3}{*}{ Std. Deviation } & \multirow[b]{3}{*}{ Std. Error } & $95 \% \quad$ Confic & Interval & \\
\hline & & & & & \multicolumn{4}{|l|}{ Mean } \\
\hline & & & & & Lower Bound & Upper Bound & Minimum & Maximum \\
\hline lower than average & 8 & 3.0192 & .39811 & .14075 & 2.6864 & 3.3521 & 2.54 & 3.31 \\
\hline average & 57 & 3.3198 & .72449 & .09596 & 3.1276 & 3.5121 & 2.38 & 4.69 \\
\hline higher than average & 75 & 4.1641 & .65909 & .07611 & 4.0125 & 4.3157 & 2.77 & 4.92 \\
\hline Total & 140 & 3.7549 & .80612 & .06813 & 3.6202 & 3.8896 & 2.38 & 4.92 \\
\hline
\end{tabular}

Table 12. ANOVA Test of Parents' Level of Income and their Involvement and Attitude

\begin{tabular}{lllccc}
\hline & Sum of Squares & df & Mean Square & F & Sig. \\
\hline Between Groups & 27.677 & 2 & 13.839 & 30.262 & .000 \\
Within Groups & 62.649 & 137 & .457 & & \\
Total & 90.326 & 139 & & & \\
\hline
\end{tabular}

According to the above tables 11 and 12 and the results of ANOVA, the statistical significant level is below 0.05, $(p<0.05)$, showing that the differences are significant. In other words, there is a significant difference between parents' level of income and their involvement in and attitude toward their children's English language programs. 


\section{Discussion}

This section is to investigate and examine the consistency of the results of the present study mentioned above with what experts have theoretically stated and what similar studies have practically done. Before discussing the results, It should be mentioned that no exact research was found to compare and check whether the outcomes of this research are in accordance with the results of them or not.

The results of numerous studies revealed that parental involvement had a potential to improve student achievement and behavior (Bourdieu and Passeron, 1990; De Graaf, 1986; Farkas et al., 1990). Also, Buchmann et al. (2010) indicated that the benefits of parental involvement incorporated higher test scores and grades, better school attendance, greater completion percentage of homework, more positive attitudes and behavior, superior graduation rates and greater enrollment in higher education.

Specifically, the results of the present study are in harmony with the results of the study by Cansler, (2008), in which the direct correlation between parental attitude and involvement in various capacities of schooling and student achievement has been demonstrated in empirical investigations.

More specifically, similar to the findings of further outcomes of the study mentioned before, Jang (2012) found parents' attitudes, motivations, and involvement can be affected by a variety of personal characteristics such as age, gender, educational levels, income etc.

All in all, similar to findings of this study, a lot of research have reported that parental involvement and positive attitude has a major influence on all students' academic and overall success in general and language learning in specific (Epstein \& Sanders, 2000; Henderson \& Mapp, 2002; Henrich \& Gadaire, 2008; Weiss, Caspe, \& Lopez, 2006).

\section{Conclusion}

The overall aim of this research was to evaluate the effect of parents' involvement in and attitude toward their children's foreign language programs for learning English in Iran. As the results revealed, the students whose parents have high level of involvement in and positive attitude toward their children's English language programs learn and achieve more in the programs. In other words, the parents who have high level of involvement in and positive attitude toward their children's English language programs caused their children's higher level of achievement in the language program.

According to the outcomes the next four questions were also answered. First, there is a significant difference between parents' knowledge of English and their involvement in and attitude toward their children's English language programs. Their knowledge of English leads to their higher involvement level and more positive attitude. Second, there is not a significant difference between parents' gender and their involvement in and attitude toward their children's English language programs. In other words, the parents' gender does not affect their level of involvement and strength of attitude. Third, there is a significant difference between parents' level of educational background and their involvement in and attitude toward their children's English language programs. The more they are educated, the higher is their level of involvement and the more positive attitude they have toward their children's English language programs. Fourth, there is a significant difference between parents' level of income and their involvement in and attitude toward their children's English language programs. The higher their income level is, the higher level of involvement and strength attitude they have toward their children's English language programs.

\subsection{Pedagogical Implication}

Broadly speaking, the review of literature in this study reveals that how important and effective it is to hold language programs from very early ages. More specifically, establishing language programs in which English is a mandatory subject for primary school is highly recommended.

In fact, this study gathered information that will help them make effective decisions. As it was concluded, the results showed parents' high level involvement in and attitude toward their children's English language programs lead to their children's improvement and achievement. Thus, education stakeholders should hold teacher-parent meetings in which they make parents aware of their crucial roles in their children's education.

\section{References}

August, D., and Hakuta, K. (1997). Improving schools for language minority children: A research agenda. Washington, DC: National Academy Press.

Baker, C., (1992). Attitudes language. Clevedon: Multilingual Matters.

Ballantyne, K.G., Serman, A. R., McLaughlin, N., (2008). Dual language learners in the early years: Getting to succeed in school. Washington, DC: National Clearinghouse for English Language Acquisition.

Birdsong, D. and Molis, M. (2001). On the evidence for maturational constraints in second language acquisition. $J$. Memory Lang., 44, 235-249. DOI:10.1006/jmla.2000.2750

Bohner, G., and Dickel, N. (2011). Attitudes attitude change. Annual Review of Psychology

Bourdieu, P. and J.C. Passeron (1990). Reproduction in Education, Society Culture. 2nd Edn., SAGE Publications, London, ISBN-10: 0803983204, pp: 254. 
Brown, H. D. (2007). Principles of language learning teaching. 5thed. NY: Longman, White Plains.

Buchmann, C., D.J. Condron and V.J. Roscigno (2010). Shadow education, American style: Test preparation, the SAT college enrollment. Social Forces, 89, 435-461. DOI: 10.1080/00221309.2013.783779

Buttery, J. T., and Anderson, J. P. (1999). Community, schools, parent dynamics: A synthesis of literature activities. Teacher Quarterly Education, 111-122.

Carter, R. and Nunan, D. (2001). The Cambridge guide to teaching English to speakers of other languages. Cambridge University Press.

Chalak, A., and Kassaian, Z. (2010). Motivation attitudes of Iranian undergraduate EFL students towards learning English. GEMA Online ${ }^{\mathrm{TM}}$ Journal of Language Studies, 10(2), 37-56.

Clark, C. and Hawkins, L. (2010). Young People's Reading: The Importance of the home environment family support. National Literacy Trust, 1-32.

Cotton K. and Wikelund K. (2001). Parent involvement in education. Available online at Northwest Regional Education Laboratory www.nwrel.org/scpd/sirs/3/cu6.htmlS

Craig, B. (1996). Parental attitudes toward bilingualism in a local two-way immersion program. Bilingual Research Journal, 20(3and4), 383-410.

Csizer, K. and Dörnyei, Z. (2005). The internal structure of language learning motivation its relationship with language choice learning effort. The Modern Language Journal, 89, 19-36.

De Graaf, P.M. (1986). The impact of financial cultural resources on educational attainment in the Netherls. Sociol. Educ., 59, 237-246. DOI:10.2307/2112350

Desforges, C. and Abouchaar, A. (2003). The impact of parental involvement, parental support family education on pupil achievement adjustment: A literature review. Department for Education Skills Research Report 433.

Epstein, J. L., and Sanders, M. G. (2000). Connecting home, school, community: New directions for social research. In M. T. Hallinan (Ed.), Hbook on the Sociology of education (pp. 285-306). New York, NY: Kluwer Academic/Plenem.

Farkas, G., Grobe, R., Sheehan, D., and Shuan, Y., (1990). Coursework mastery school success: gender, ethnicity, poverty groups within an urban school district. American Educational Research Journal 27, 807-827.

Feuerstein, R. (1990). The theory of structural modifiability. In B. Presseisen (Ed.), Learning thinking styles: Classroom interaction. Washington, DC: National Education Association.

Gardner, R. C. (1985). Social Psychology Second Language Learning. London: Edward Arnold.

Giacchino-Baker, R., and Piller, B. (2006). Parental Motivation, Attitudes, Support, Commitment in a Southern Californian Two-Way Immersion Program. Journal of Latinos Education, 5(1), 5 -28.

Greenwood, G. E., and Hickman, C. W. (1991). Research practice in parent involvement: Implications for teacher education. Elementary School Journal, 91(3), 279-288.

Griva, E., and Chostelidou, D. (2011). Multilingual competence development in the Greek educational system: FL teachers' beliefs attitudes. International journal of multilingualism, 1-15.Multilingual matters.

Harvard Family Research Project. (2006). http://www.hfrp.org/publications-resources/browse-our-publications/familyinvolvement-makes-a-difference-in-school-success

Henderson, A. T. and Mapp, K. L. (2002). A new wave of evidence: The impact of school, family, communityconnections on student achievement. Austin, TX: National Center for Family and Community Connections with Schools, Southwest Educational Development Laboratory.

Henrich, C. and Gadaire, D. (2008). Head Start parental involvement. Infants Young Children, Vol. 21(1), 56-69.

Jang, B. (2012). Reducing instruction, increasing engagement [blog post]. Available:

http://blog.stenhouse.com/archives/2012/07/23/blogstitute-week-5-reducing-instruction-increasing-engagement/

Keith, T. Z., and Keith, P. B. (1993). Does parental involvement affect eights-grade student achievement? Structural analysis of national data. School Psychology Review, 22(3), 474-496.

Latif, M., Rahmany, R. and Hassani, MT. (2013). the effects of teacher-parent relationships on Iranian EFL learners' language proficiency. International Journal of Language Learning Applied Linguistics World, 4(3), 293-302.

McGroarty, M. (1997). Language policy in the USA: National values, local loyalties, pragmatic pressures. In W. Eggington, and H. Wren (Eds.), Language policy (67- 90). Philadelphia, PA: John Benjamins Publishing Company.

McLendon Cansler, L. E. (2008). Parent attitudes about involvement with foreign language programs for elementary students. Doctoral dissertation, University of North Carolina, Chapel Hill.

Mitchell, R. and Myles, F. (2004). Second language learning theories. Oxford: Oxford University Press.

Nespor, J. (1987). The role of beliefs in the practice of teaching. Journal of Curriculum Studies, 19(4), 317-328.

Oladejo, J. (2006). Parents' attitudes towards bilingual education policy in Taiwan. Bilingual Research Journal, 30(1), 147-170. 
Oncu, E., and Unluer. E. (2010). Preschool children's using of play materials creatively. Procedia Social Behavioral Sciences, 2(2), 4457-4461.

Rosenbusch, M., H., (1987), "Second language learning in young children ". Retrospective Theses Dissertations. Paper 8581. bhttp://lib.dr.iastate.edu/rtd/8581

Sadeghi, A. R. (2005). ESP in Iran: A transition from present state. In: G. R Kiany, M. Khayyamdar, (Eds.), Proceedings of the First National ESP/EAP Conference, 2, Tehran.

Share, M., Kerrins, L., and Greene, S., (2011). Developing Early Years Professionalism, Ireland.

Sheldon, S. B. (2002). Parents' social networks beliefs as predictors of parent involvement. The Elementary School Journal, 102, 301-316.

Tse, L. (1998). Ethnic identity formation its implications for heritage language development. In S. Krashen, L. Tse, and J. McQuillan (Eds.), Heritage languagedevelopment (pp. 15-29). Culver City, CA: Language Education Associates.

Vaezi, Z. (2008). Language Learning Motivation among Iranian Undergraduate Students. World Applied Sciences Journal, 5(1), 54-61.

Wang, L. and H. Chang, (2011). Improve oral training: The method of innovation assessment on English speaking performance. Int. J. Distance Educ. Technol., 9, 56-72. DOI: 10.4018/jdet.2011070105

Waterman, R., and Harry, B. (2008). Building collaboration between schools parents of English language learners: Transcending barriers, Creating Opportunities. Culturally Responsive Educational Systems: Education for All, 1-24.

Weiss, H. B., Caspe, M., and Lopez, M. E. (2006). Family involvement in early childhood education. Cambridge, MA: Harvard Family Research Project.

Whitmarsh, J. (2009). Othered voices: asylum-seeking mothers early years education. European Early Childhood Education Research Journal, 19(4), 535 - 551

Williams, M., and Burden, R. (1997). Psychology for language teachers: a social constructivist approach. Cambridge: Cambridge University Press.

Young, A. S. (1994). Motivational State Process within the Socio-Linguistic Context. Birmingham: Aston University.

\section{Appendix}

\section{Questionnaire}

Please check the item that best describes the experiences of your child and yourself.

\begin{tabular}{|c|c|c|c|c|c|}
\hline & $\begin{array}{c}\text { Strongly } \\
\text { Agree }\end{array}$ & Agree & $\begin{array}{c}\text { Not } \\
\text { Applicable }\end{array}$ & Disagree & $\begin{array}{l}\text { Strongly } \\
\text { Disagree }\end{array}$ \\
\hline \multicolumn{6}{|l|}{$\begin{array}{l}\text { 1. My child talks positively at home about foreign } \\
\text { language class. }\end{array}$} \\
\hline \multicolumn{6}{|l|}{$\begin{array}{l}\text { 2. My child's comments are positive about foreign } \\
\text { language learning. }\end{array}$} \\
\hline \multicolumn{6}{|l|}{$\begin{array}{l}\text { 3. My child feels successful in the foreign language } \\
\text { class. }\end{array}$} \\
\hline \multicolumn{6}{|l|}{ 4. My child likes the foreign language. } \\
\hline \multicolumn{6}{|l|}{ 5. My child likes the foreign language teacher. } \\
\hline \multicolumn{6}{|l|}{$\begin{array}{l}\text { 6. I am receiving enough information about the foreign } \\
\text { language program at the school. }\end{array}$} \\
\hline \multicolumn{6}{|l|}{$\begin{array}{l}\text { 7. I have seen my child performing in a foreign } \\
\text { language school program. }\end{array}$} \\
\hline \multicolumn{6}{|l|}{ 8. I have visited my child's foreign language classroom. } \\
\hline \multicolumn{6}{|l|}{$\begin{array}{l}\text { 9. My child brings home useful foreign language } \\
\text { worksheets, song handouts, or information. }\end{array}$} \\
\hline \multicolumn{6}{|l|}{ 10. My child uses foreign language frequently at home. } \\
\hline \multicolumn{6}{|l|}{$\begin{array}{l}\text { 11. I am in favor of teaching a foreign language to } \\
\text { children. }\end{array}$} \\
\hline \multicolumn{6}{|l|}{$\begin{array}{l}\text { 12. I feel that studying foreign language has not } \\
\text { jeopardized my child's progress in other subject areas, } \\
\text { such as math or reading }\end{array}$} \\
\hline $\begin{array}{l}\text { 13. My child is benefiting from the elementary foreign } \\
\text { language program at our school. }\end{array}$ & & & & & \\
\hline
\end{tabular}


Now we have a few questions about you and your child. Please mark the blank next to your answer for each of the following items.

1. Is your child receiving additional foreign language instruction outside of the school program?

Yes

No

2. Can you speak English?

Yes

No

3. What is your gender?

Male

Female

4. What is your educational background?

Bellow diploma

Diploma

Bachelor's degree

Master's degree or higher

5. In 2014, what was your family's monthly income?

Lower than average

Average

Higher than average

Additional comments: If you feel this questionnaire did not allow you to adequately express your opinion, or if you would care to elaborate on a particular point(s), please do so in the space below.

Thank you for your time. 